\title{
KONSELING ONLINE SEBAGAI UPAYA MENANGANI MASALAH PERUNDUNGAN DI KALANGAN ANAK MUDA
}

\author{
Anaway Irianti Mansyur'1, Aip Badrujaman², Rochimah Imawati ${ }^{3}$, Dini Nur \\ Fadhillah4 \\ 1,2Program Studi Bimbingan Konseling, Pascasarjana, Universitas Negeri Jakarta \\ ${ }^{3}$ Program Studi Manajemen Dakwah, Fakultas Dakwah dan Ilmu Komunikasi, UIN \\ Syarif Hidayatullah Jakarta \\ ${ }^{4}$ Program Studi Pendidikan Pancasila dan Kewarganegaraan, Pascasarjana, \\ Universitas Sebelas Maret \\ e-mail: wayirianti@gmail.com
}

\begin{abstract}
The presence of technology is changing the way people to get information and communication. In the field of counseling, information technology offers some of the latest innovations to reach out, facilitate and communicate with individuals who need help from all over the world. This qualitative research collected data through literature study by analyzing 5 research results from various academics in various countries and conducting interviews with 10 youth aged 19-23 years, and 3 counselors. The results of this qualitative study indicate that online counseling makes it easy for youth in expressing the problem in their life. In addition, online counseling has great potential in offering therapy and can be done anywhere. Therefore, clients can minimize transportation costs for face-to-face counseling. Although the results of the analysis of previous studies indicate that online counseling has a weakness that is lack of knowledge and special abilities possessed by counselors in communicating through chat and lack of skills in writing texts to avoid misunderstandings with online counseling users. In the other side, previous research shows solutions related to the use of online counseling. The counselor must face the development of technology and use it as a facility to communicate with young people.
\end{abstract}

Keywords: online counseling, bullying, youth

\section{PENDAHULUAN}

Internet menjadi sarana penting dalam memberikan layanan kesehatan mental kepada kaum muda (King, Bambling, Lloyd, Gomurra, Smith, Reid, \& Wegner, 2006; King, Spooner, \& Reid, 2003; Mallen, Vogel, Rochlen, \& Day, 2005). Hadirnya internet juga dapat mengatasi hambatan berkaitan dengan jarak dan akses, dan anonim. Berdasarkan Organisasi Kesehatan Dunia (2004) mendefinisikan kesehatan mental sebagai sesuatu keadaan kesejahteraan di mana individu menyadari kemampuannya sendiri, dapat mengatasinya dengan tekanan normal kehidupan, dapat bekerja secara produktif dan berbuah, dan sedang mampu memberikan kontribusi kepada komunitasnya. Sehingga kesehatan mental tidak semata-mata hanya karena tidak adanya penyakit mental, melainkan spektrum kesejahteraan (Galderisi et al., 2015). Menurut Survei Kesehatan Mental Dunia WHO, gangguan mental berkisar antara 12\%-47\% (Kessler et al., 2007). Namun, beberapa orang sering kali tidak mencari bantuan untuk masalah kesehatan 
mental. Ada beberapa hambatan mencari pengobatan yang terlibat, termasuk stigma yang terkait dengan penyakit mental, kurangnya sumber keuangan, jumlah energi dan waktu yang dibutuhkan untuk mencari bantuan, serta beberapa orang yang belum mengetahui di mana menemukan layanan yang memadai (Tartakovsky, 2013). Anak muda mungkin lebih suka menggunakan akses internet untuk membutuhkan bantuan dan merasa nyaman bekerja (King, Bambling, Lloyd, et al., 2006; Nicholas, Oliver, Lee, \& O'Brien, 2004). Penelitian pendahuluan tentang preferensi dan karakteristik anak muda yang menggunakan konseling online (King, Bambling, Lloyd, et al., 2006; Leibert, Archer, Munson, \& York, 2006) dan keefektifan dari konseling online (King, Bambling, Reid, \& Thomas, 2006; Mallen et al., 2005). Hanley (2006) juga menyimpulkan bahwa konseling online memiliki potensi besar; Namun, ada tantangan yang harus diatasi tentang regulasi layanan dan praktik terbaik model untuk kaum muda.

Di Indonesia sendiri, kehadiran konseling online masih relatif dan belum begitu terkenal. Sedangkan di beberapa negara, konseling online berbasis web-chat semakin sering digunakan untuk memberikan dukungan dan perawatan kepada orang yang mengalami masalah dengan kesehatan mental, perjudian, kecanduan, dan berbagai masalah lain (Dowling \& Rickwood, 2013; Gainsbury \& Blaszczynski, 2011; Rodda, Lubman, Dowling, \& McCann, 2013b; Sucala et al., 2012). Meskipun layanan cenderung menargetkan orang yang mengalami masalah, banyak juga layanan yang memberikan dukungan untuk keluarga mereka dan teman-teman. Keluarga memiliki kebutuhan dukungan khusus yang mungkin berbeda dari orang lain yang mencari dukungan (Wilson, Rodda, Lubman, Manning, \& Yap, 2017b); Namun, penelitian telah berfokus pada bagaimana konseling online mampu melayani keluarga yang berkebutuhan khusus. Dalam penelitian tersebut, peneliti menggunakan konseling online sebagai contoh empiris untuk mengeksplorasi bagaimana fitur web tersebut dapat mendukung keluarga yang mencari bantuan secara online atau membatasi peluang.

Meskipun berbeda dengan penelitian sebelumnya, di Indonesia ada beberapa aplikasi yang menawarkan konseling online secara gratis seperti KALM. Aplikasi KALM merupakan salah satu konseling online yang memberikan kesempatan bagi kalangan anak muda yang memiliki masalah dan menyediakan konselor professional sesuai dengan kebutuhan secara online (KALM, 2020). Sehingga, konseling online bukan hanya untuk keluarga berkebutuhan khusus tetapi juga kalangan anak muda.

Bimbingan dan konseling sebagai salah satu komponen dalam pendidikan juga memanfaatkan teknologi informasi. Bimbingan dan konseling sebagai sebagai salah satu bidang yang memanfaatkan teknologi informasi perlu memperhatikan perkembangan teknologi infromasi untuk bisa diterima oleh masyarakat. Penguasaan teknologi informasi bagi seorang konselor merupakan keharusan yang harus dimiliki dan tidak bisa ditawar lagi, Hal tersebut didasari oleh perkembangan teknologi informasi yang semakin maju dan berkembang pesat. Keuntungan utama konseling online adalah kemudahan anggota keluarga dan teman-teman dapat masuk ke dalam sesi, bahkan ketika mereka tinggal di daerah yang berbeda. Bayangkan seorang perokok remaja, yang orang tuanya bercerai membutuhkan konseling untuk diri mereka sendiri. Dalam sesi tatap muka, sulit 
orang tua yang bekerja untuk terlibat dalam sesi reguler, tetapi secara online relatif mudah melibatkan keduanya.

Pada saat memberikan konseling, penting untuk menasihati anggota keluarga, karena memang demikian adanya bahwa anggota keluarga selalu terlibat baik sebagai kontributor atau sebagai pengamat dengan perilaku kalangan anak muda. Seringkali, masalah kesehatan untuk seseorang juga masalah untuk yang lain. Sehingga penting untuk melibatkan keluarga. Kalangan anak muda dan keluarga berbagi lingkungan yang sama dan resolusi kalangan anak muda untuk mengubah tidak dapat dipertahankan seiring waktu tanpa penyesuaian di lingkungan bersama. Di India, tepatnya di daerah Madhya Pradesh terdapat layanan $e$ governance yang diluncurkan selama beberapa tahun terakhir. Untuk mewujudkan konseling online pemerintah di India menggunakan layanan elektronik yang ditawarkan melalui e-governance yang terintegrasi dengan portal bermerek yaitu MPONLINE (www.mponline.gov.in/) (Chatterje, 2014). Namun, layanan yang diberikan terkait dengan konsultasi pendidikan serta karir yang akan di pilih pada (www.mponline.gov.in/Portal/CitizenHome.aspx?Servtypeid8\#). Misalnya, Departemen Pendidikan Tinggi menyediakan layanan konseling online untuk mereka yang ingin masuk di dalam program lain seperti Direktorat Pendidikan Kedokteran menawarkan layanan konseling online untuk program akademik yang berkaitan dengan pendidikan kedokteran gigi; Direktorat Teknis Pendidikan menawarkan hal yang sama untuk program gelar akademik seperti teknik, arsitektur, farmasi, manajemen hotel, administrasi bisnis, manajemen terapan, master aplikasi dan komputer; Direktorat Layanan Kesehatan menawarkan hal yang sama untuk pengangkatan petugas medis; Direktorat Pengembangan Keterampilan menawarkan hal yang sama untuk kursus kejuruan di lembaga pelatihan industri negara; Direktorat Publik Administrasi menawarkan hal yang sama untuk perekrutan guru kontrak.

Di negara India konseling online tidak hanya memberikan layanan untuk berkonsultasi mengenai masalah pribadi tetapi juga pendidikan dan karir. Untuk itulah konseling online merupakan sebuah kebutuhan yang mendesak. Maka dari itu diperlukan aplikasi yang memadai untuk menangani risiko kerahasiaan, mengembangkan kebijakan yang jelas mengenai peraturan praktik tersebut, fokus dalam upaya penelitian untuk menentukan efektivitas konseling online, dan menetapkan standar praktik terbaik mengenai ketentuan konseling online. Menurut Kurt D. Baker \& Mike Ray (2011) ada sedikit penelitian yang sebenarnya mengatasi salah satu dari masalah tersebut. Dengan tidak adanya penelitian, kebijakan, dan praktik yang baik akan terus didasarkan pada asumsi dan preseden historis. Dengan kata lain, karena layanan seperti itu diluncurkan tanpa masalah besar ini ditangani, hal itu mengharuskan komunitas riset untuk memeriksa apa yang terjadi di pada konseling online. Kurangnya standar saat ini telah menyebabkan bidang intervensi terapeutik yang didukung internet menjadi sangat tidak terstruktur (Barak, Klein, \& Proudfoot, 2009). Kurangnya kejelasan dan konsistensi juga tercermin dalam berbagai istilah yang sering digunakan secara bergantian seperti cyberpsikologi, telepsikologi, terapi online, e-health, telehealth, konseling web, konseling elektronik, dan konseling online (Barak et al., 2009; Beidoğlu et al., 2015; Chester \& Glass, 2006; Perle, Langsam, \& Nierenberg, 2011). Dalam artikel ini, konseling online didefinisikan sebagai praktik konseling 
profesional yang terjadi ketika seorang kalangan anak muda dan seorang psikolog berlisensi berada di tempat yang jauh dari lokasi dan interaksinya berlangsung menggunakan teknologi informasi. Komunikasi ini menggunakan dua arah, sinkron atau asinkron, yang dapat digunakan baik sebagai fungsi yang berdiri sendiri atau sebagai pelengkap komunikasi tatap muka tradisional. Hal ini juga melibatkan pengguna email, obrolan, forum, konferensi video, situs web, dan aplikasi untuk perangkat seluler. Instrumen teknologi kehidupan sehari-hari seperti komputer, smartphone, tablet, dan koneksi internet (Maheu, Pulier, McMenamin, \& Posen, 2012).

Hanley dan Reynolds (2009) menyelesaikan meta-analisis dari lima studi secara khusus menargetkan aliansi terapeutik dalam konseling online. Lima studi ini, berjumlah 161 peserta, memeriksa manusia-ke-manusia yang sedang berlangsung hubungan terapeutik yang dipertahankan melalui komunikasi yang dimediasi komputer. Empat dari lima penelitian menggunakan tatap muka yang telah dilakukan sebelumnya yaitu kelompok pembanding. Tiga dari empat studi ini menunjukkan bahwa sebagai perbandingan, aliansi online dinilai lebih tinggi daripada dalam perbandingan tatap muka kelompok. Secara keseluruhan, review mendukung pendapat bahwa terapi yang terukur aliansi dapat dibentuk melalui terapi yang dimediasi komputer. Basis literatur yang sedikit ini menunjukkan perlunya lebih banyak penelitian yang dimediasi komputer konseling, terlepas dari kurangnya penelitian untuk sepenuhnya membuktikan penggunaan tersebut. Manfaat konseling online untuk kalangan anak muda tercakup dalam sebagian besar literatur dan diuraikan beberapa manfaat dari cara kerja baru seorang konselor menggunakan teknologi informasi, kemudian seputar masalah kontrol kalangan anak muda. Cohen and Kerr's (1998) dalam Wright (2002) melakukan studi empiris dengan membandingkan antara efek konseling yang dilakukan berbasis online dengan konseling tatap muka secara tradisional mengenai kecemasan dan sikap terhadap konseling. Penelitian tersebut menunjukkan bahwa, terapis yang menawarkan konseling online harus waspadai kontrol tinggi yang dimiliki oleh kalangan anak muda. Melalui penelitian ini, peneliti lebih concern terhadap hasil penelitian konseling berbasis online terhadap kalangan anak muda untuk menelaah terkait perkembangan teknologi dengan bimbingan konseling.

Berdasarkan hasil analisis Alat Ungkap Masalah (AUM) yang disebarkan kepada 60 orang kalangan anak muda usia 19 - 23 tahun di Jakarta Barat dan Jakarta Selatan pada saat Program Sosialisasi Konseling Online pada bulan November 2019, ditemukan 3 aspek masalah tertinggi yang dihadapi oleh kalangan anak muda. Hasilnya menunjukkan bahwa aspek masalah tertinggi yang pertama ada di bidang karier dan pekerjaan yaitu sejumlah $50 \%$ item. Kedua, adalah di aspek diri pribadi yaitu sebesar 35\%. Ketiga, adalah aspek jasmani dan kesehatan yaitu sebesar 25\%. Kemudian, di bagian lembar jawaban uraian mengenai gambaran keseluruhan masalah, ada sekitar 50\% anak muda menyatakan memerlukan konseling akan masalahnya. Namun pada kolom keinginan melakukan konseling terhada siapa, sebagaian dari mereka menyatakan akan lebih nyaman untuk sekedar bercerita dengan teman maupun media sosial. Selanjutnya, lembar jawaban mengenai konseling online menunjukkan bahwa 70\% masih belum memahami terkait aplikasi yang menawarkan konseling online. Disisi 
lain masalah pribadi yang sering muncul terkait perundungan Beberapa penelitian perundungan siber di Indonesia pernah dilakukan.

Perundungan di kalangan siswa di sekolah pernah dilakukan oleh Rahayu (2012) dan Maya (2015). Kemudian bentuk perundungan siber di media sosial dan pencegahannya dilakukan oleh Rastati (2016). Perundungan siber terhadap anak dan orang dewasa pernah dikaji oleh Safaria (2015). Selain itu, penelitian perundungan yang terjadi di tempat kerja dilakukan oleh Silviandari (2018). Namun demikian, penelitian terkait tentang upaya menangangi masalah perundungan melalui konseling online. Sehingga dibutuhkan analisis terkait konseling berbasis online khususnya di kalangan anak muda. Data awal ini menjadi landasan peneliti untuk melakukan analisis lebih mendalam terkait konseling online diberbagai negara dan penelitian sebelumnya serta penerapanya di Indonesia. Diharapkan kedepannya konseling online dioptimalkan fungsinya, khususnya dalam memberikan layanan konseling jarak jauh. Serta dapat dijadikan sebagai alternatif kalangan anak muda untuk mendapatkan kenyamanan dalam bercerita mengenai masalahnya. Untuk mewujudkan hal itu, pada penelitian ini peneliti mengambil judul penelitian "Konseling Online sebagai Upaya Menangani Masalah Perundungan di Kalangan Anak Muda".

\section{METODE PENELITIAN}

Penelitian ini menggunakan pendekatan kualitatif (Creswell, 2014). Pengumpulan data dilakukan dengan studi pustaka yaitu pencarian juga termasuk daftar referensi dari artikel yang disaring, abstrak konferensi, dan data yang tidak dipublikasikan. Dari 20 artikel Emerald, 19 artikel Taylor \& Francis, 10 artikel Springer dan 10 artikel Sage dilakukan filterisasi sesuai dengan topik untuk itu menjadi 5 artikel yang terpilih terkait dengan konseling berbasis online; perundungan; dan kalangan anak muda. Setelah melakukan studi pustaka, peneliti melakukan wawancara terhadap 10 kalangan muda usia 19-23 tahun dari berbagai macam latar belakang yaitu 5 pekerja, 3 mahasiswa dan 2 belum bekerja. Wawancara juga dilakukan kepada 3 orang konselor. Dibawah ini merupakan siklus penelitian kualitatif:

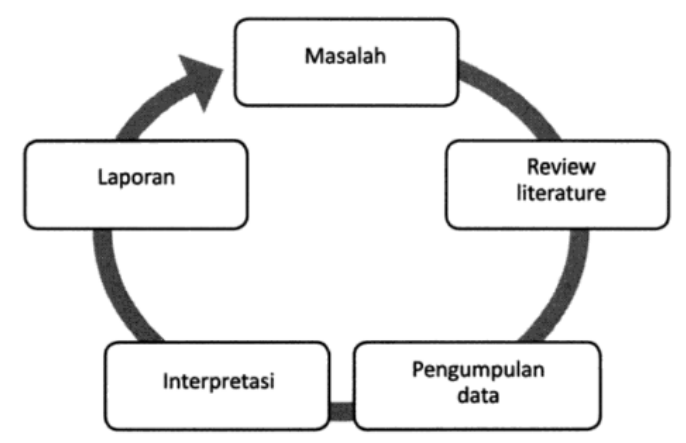

Gambar 1.

Penelitian Kualitatif Menurut Creswell (2014)

Wawancara informan dilakukan untuk memahami terkait dengan konseling online. Informasi yang disampaikan oleh informan kemudian dikumpulkan dan dianalisis. Sehingga hasil analisis tersebut dapat dideskripsikan. Penelitian kualitatif terkait 
konseling online ini dipengaruhi oleh pandangan, pemikiran dan pengetahuan peneliti serta informan.

\section{HASIL DAN PEMBAHASAN}

Dari hasil analisis terhadap 59 artikel terkait konseling online berikut adalah 5 artikel terpilih yang sesuai dengan tujuan analisis pada artikel ini yaitu:

1. Online Counselling: The experience of Counsellors Providing Synchronous Single-Session Counselling to Young People (Bambling, King, Reid \& Wegner, 2008)

Pada penelitian ini menggunakan metode penelitian kualitatif konsensual yang dirancang menggunakan sampel kecil untuk menganalisis data kelompok yang terarah dari anak muda berdasarkan pengalaman mereka menggunakan layanan konseling online di KHL (Kids Help Line). KHL merupakan konselor profesional yang memberikan layanan konseling online dan telepon bagi warga Negara Australia untuk memberikan konseling kepada anak muda. Konselor melaporkan intensitas emosi yang lebih rendah ketika berinteraksi dengan anak muda secara online daripada konseling melalui telepon. Mereka mengindikasikan bahwa semakin rendah intensitas emosional memiliki manfaat untuk kalangan anak muda dan konselor. Hal ini lebih mudah bagi kalangan anak muda mengkomunikasikan masalah yang kompleks dan emosional. Kemudian, dalam penelitian ini memberikan kesempatan pada konselor untuk melakukan respon melalui tanggapan pemikiran terhadap kalangan anak muda. Peserta dipersepsikan memiliki kekuatan keseimbangan antara konselor dan kalangan anak muda menjadi lebih setara secara online daripada di telepon konseling. Konselor menghubungkan ketegasan yang lebih besar kepada kalangan anak muda di lingkungan online ke internet sehingga kurangnya kedekatan langsung dengan konselor dan keamanan emosional. Konselor juga menyarankan agar keselamatan emosional kalangan anak muda dilakukan tanpa hambatan, karena mereka 'berbicara tentang keprihatinan mereka dari pernyataan pertama mereka. Konselor mencatat lebih rendah resistensi di lingkungan online, hal ini dikarenakan kalangan anak muda kurang puas untuk mengajukan pertanyaan pribadi kepada konselor melalui web dan langsung ke titik sesi. Meskipun begitu, sisi positifnya konseling online memberikan keamanan anak muda dalam meluapkan emosi, karena berkurangnya emosi kalangan anak muda memudahkan konselor untuk melakukan pendekatan. Kerugian dari berkurangnya kedekatan emosional atau perbedaan pada saat tatap muka, termasuk tidak adanya isyarat non-verbal dan menilai anak muda tidak akurat. Penelitian ini menunjukkan bahwa dibutuhkan metode untuk terus meningkatkan proses keduanya dan efektivitas konseling online yang dibutuhkan. Sehingga memperpanjang durasi sesi merupakan salah satu cara untuk meningkatkan efektivitas konseling online. Namun, disisi lain peningkatan biaya konseling terjadi. Hal ini lebih produktif, karena konselor dapat memanfaatkan pertanyaan pra-konseling untuk mengaktifkan pengumpulan data informasi kalangan anak muda secara interaktif dan identifikasi terkait masalah, sasaran, faktor konsektual dan sumber daya kalangan anak muda tanpa memerlukan kehadiran langsung. Sehingga konselor dapat meninjau informasi sebelum memulai konseling dan memanfaatkan waktu konseling secara optimal. 
2. Counseling Activity in Single-Session Online Counseling with Adolescents: An Adherence Study (Chardon, Bagraith, \& King, 2011)

Penelitian ini menjelaskan bahwa konseling online menjadi sangat popular bagi mereka yang membutuhkan untuk konseling. Internet sebagai media yang termasuk unik mempermudah penggunanya dalam melakukan akses sumber bantuan formal seperti orang yang profesional dalam kesehatan mental. Menurut data National Review of Australian Tele and Web melaporkan bahwa konseling online memberikan anak-anak dalam memiliki sebuah privasi yang lebih besar dan terkontrol. Chardon, Bagraith dan King mencoba untuk melakukan penyelidikan terkait kegiatan dan proses konseling yang digunakan pada layanan konseling online untuk remaja. Proses penelitian yang dilakukan adalah menyelidiki proses, keefektifan dan pengalaman pengguna layanan konseling online Kids Help Line. Kemudian peneliti memetakan proses konseling online untuk memahami apa saja yang terjadi pada sesi konseling online. Penelitian ini menggunakan studi exploratory naturalistic yang menyelidiki aktivitas konseling dalam konseling berbasis online pada remaja. Standar yang digunakan dalam proses pengumpulan data mengikuti pedoman National Health and Medical Research Council Australia. Data yang diambil dari 85 transkrip konseling online yang kemudian dikumpulkan untuk membandingkan antara konseling online dan konseling melalui telepon. Konseling dilakukan melalui pertukaran teks pada Kids Helpline Web. Dari 85 transkrip, $45(52,9 \%)$ memenuhi kriteria untuk kepatuhan dalam kemajuan melalui setiap tahap model konseling (total kemajuan minimal 5 dan termasuk setidaknya satu skor kemajuan dalam setiap tahap konseling). Konseling berbasis online akan terus memainkan peran penting dalam menyediakan akses pelayanan, terutama untuk remaja. Oleh karena itu penting untuk mengembangkan cara yang lebih efektif lagi, dapat digunakan pelayanan konseling berbasis online.

\section{The Effect of Counselling-Based Training on Online Peer Support (Lekka, Efstathiou, \& Azizi, 2014)}

Penelitian ini didasari oleh internet dan aplikasi yang sedang berkembang dan menawarkan berbagai cara untuk berinteraksi dengan orang lain. Tujuan utama dari penggunaan internet yaitu mengumpulkan informasi, komunikasi interpersonal dan hiburan. Tujuan dari penelitian ini adalah untuk menyelidiki dampak dari pelatihan online peer support dengan membandingkan intervensi peer supporters terlatih dengan peer supporter's yang tidak terlatih. Karena banyak institusi akademik menawarkan layanan kesehatan mental untuk memfasilitasi para mahasiswa menyesuaikan dengan perkembangan yang baru dan kebutuhan akademik. Secara independen bagaimana efektif layanan ini adalah, kaum muda lebih cenderung mencari dukungan dari anggota keluarga atau teman daripada dari seorang ahli. Sehingga peer supporters membutuhkan dukungan secara terus menerus dan pengawasan tidak hanya berkenaan pada masalah-masalah sulit dalam pekerjaan mereka tetapi juga tantangan mengenai penempatan mereka, sementara itu profesional kesehatan mental juga harus menerima semacam pelatihan tentang peer support untuk memahami manfaatnya pada layanan ini. Sejak tahun 2008, Lekka dan Efstathiou sudah melakukan penelitian pada Laboratorium Konseling Psikologis untuk Mahasiswa di Universitas Athena dengan menawarkan forum diskusi online peer support yang disebut student to student. 
Pada penelitian ini menjelaskan bahwa forum diskusi adalah bagian dari layanan berbasis web untuk mahasiswa (http://www.med.uoa.gr) di mana mereka juga dapat menerima secara online konseling dari para profesional kesehatan mental. Tujuan utama dari forum ini adalah untuk memfasilitasi proses dukungan teman sebaya antar mahasiswa, yang mewakili kelompok yang ditandai oleh banyak kesamaan, seperti usia, pengalaman dan tantangan. Partisipasi anonim dan sukarela bertujuan untuk mengekspresi pikiran dan perasaan untuk mengurangi tekanan emosional yang disebabkan oleh tuntutan perkembangan untuk menyesuaikan diri menjadi lebih dewasa. Selanjutnya, pertukaran pengalaman dan pendapat tentang topik yang menjadi perhatian bersama bertujuan untuk menyoroti cara-cara alternatif dalam pengambilan keputusan. Forum ini terbuka untuk semua mahasiswa. Diskusi diatur ke dalam subjek kategori: hubungan romantis, hubungan keluarga, hubungan sosial, penyesuaian kesulitan, dan kesulitan akademik. Semua pesan yang diposting (pertanyaan dan jawaban) adalah bersifat publik. Forum ini buka 24 jam selama 7 hari sehingga mahasiswa dapat berpartisipasi pada kenyamanan mereka sendiri.

Sampel dalam penelitian ini menggunakan dua penilai independen yang menganalisis 746 posting (teks tertulis) yang dikirimkan oleh mahasiswa yang menawarkan bantuan dan dukungan untuk sesama mahasiswa yang berpartisipasi dalam forum diskusi online selama periode 12 bulan. Dari jumlah total posting, 589 (79\%) dikirimkan oleh moderator (peer support terlatih) dan 157 (21\%) oleh anggota forum (peer support tidak terlatih). Peer support didasarkan pada pengetahuan dan pengalaman non-profesional, empati dan saling pengertian dan untuk alasan itu penting untuk tetap berkembang secara alami. Dalam konteks ini, pertanyaannya adalah seberapa banyak dan jenis pelatihan apa yang bisa dilakukan untuk membantu, sambil memastikan bahwa proses interaksi peer-topeer terjadi secara alami tidak terganggu. Pelatihan berbasis konseling yang digunakan dalam penelitian ini tampaknya tidak mempengaruhi. Hasil sementara menunjukkan bahwa kedua kelompok berbeda dalam penggunaan keterampilan konseling, tidak ada dampak pada indeks hubungan peer support, seperti yang ditunjukkan oleh tidak adanya perbedaan untuk penerimaan kategori, pemberdayaan dan empati pada tabel perbandingan antara intervensi teman sebaya yang terlatih dan tidak terlatih. Dari hasil penelitian tersebut dapat terlihat bahwa pengguna (peer support yang tidak terlatih) hampir 16 kali lebih mungkin menggunakan pengungkapan diri di posting mereka. Peer support yang terlatih (moderator) menggunakan sekitar 30\% lebih terbuka dan pertanyaan tertutup dan 20\% lebih mungkin untuk berusaha normalisasi pengalaman sesama mahasiswa. Moderator setidaknya lima kali lebih mungkin menggunakan keterampilan yang lebih kompleks, seperti definisi masalah utama dan parafrase, sementara keterampilan pemecahan masalah digunakan secara eksklusif oleh moderator. Secara statistik signifikan asosiasi juga ditemukan untuk dorongan dalam ketegasan, penyediaan informasi dan referensi, selalu mendukung peer support yang terlatih. Kedua kelompok tidak berbeda dalam penggunaan saran praktis. 
4. Counsellor Students' Conceptions of Online Counselling in Scotland and Finland (Paterson, Laajala, \& Lehtela, 2017)

Studi ini meneliti konsep konseling mahasiswa konseling online di University of Aberdeen, Skotlandia dan Universitas Ilmu Terapan Oulu di Finlandia. Selama lima tahun terakhir penulis telah mengembangkan hubungan kerja yang kuat melalui bekerja secara kolaboratif untuk mendukung pengembangan program bersama dan penelitian. Program pelatihan konseling diuraikan di bawah ini memiliki tujuan luas yang sama, yaitu untuk mendidik konselor yang terampil, yang siap untuk masyarakat yang berubah dengan cepat dan untuk setiap masalah daring yang terkait, misalnya kecanduan internet, cyber bullying dan permasalahan pada mahasiswa yang mungkin terjadi dengan kalangan muda di masa depan. Sehingga program pendidikan konselor (Finlandia) dan pendampingan rohani serta bimbingan konseling (Skotlandia) agak berbeda karena konteks bahasa yang berbeda, sistem pendidikan dan tempat kerja konselor. Perbedaan ini juga dilatar belakangi oleh budaya seperti keahlian dalam menggunakan internet dan penggunaan bahasa Inggris dibutuhkan tetapi tidak dirasa penting untuk keperluan penelitian. Penelitian ini menggunakan studi kualitatif, di mana peneliti menyelidiki konsep yang dipegang dengan melanjutkan pengembangan profesional atau lebih dikenal dengan Continuing Professional Development (CPD) mahasiswa konseling melakukan pelatihan pengembangan profesional untuk melanjutan seputar praktik konseling tatap muka secara umum sambil meningkatkan kesadaran akan teknik konseling online. Temuan kami menunjukkan bahwa konseling online memiliki makna yang berbeda dengan sampel mahasiswa yang berbeda bahwa konsepsi internal mereka tentang apa yang dimaksud dengan konseling online dapat dikategorikan dalam 4 judul atau orientasi yang dirangkum. Para mahasiswa yang melihat konseling online dari orientasi teknis cenderung melihatnya sebagai alat yang akan digunakan untuk keterlibatan konseling secara keseluruhan atau sebagai tambahan online untuk tatap muka sesi konseling. Mereka mengaitkan tanggapan mereka dengan mencoba-coba sebelumnya dalam penggunaannya. Beberapa pengalaman dasar langsung melalui penggunaan sejumlah mode pengiriman yang disebutkan dan diuraikan dalam literatur di atas karena itu dapat diasumsikan dari tanggapan mereka. Temuan penelitian ini mendukung tujuan studi garis dasar dan pertanyaan penelitian yang diajukan dan tidak hanya menyoroti kebutuhan untuk pemahaman tentang bagaimana mahasiswa membangun konsepsi dari kepercayaan yang dihasilkan secara internal tetapi juga bagaimana pelatihan konseling online dapat dilakukan dan disosialisasikan. Maka dari itu pentingnya pelatihan spesialis konseling masa depan dalam praktik online juga diungkapkan dalam penelitian ini dan juga poin untuk persyaratan pelatihan tidak hanya untuk konselor sendiri tetapi juga untuk manajer tempat kerja mereka dan organisasi mereka. Sebagai generasi masa depan menjadi lebih terampil dalam penggunaan internet, pengembangan komunikasi sosial dan pembelajaran sangat penting. Karena banyak kalangan anak muda menjadi semakin stres ketika menghadapi masalah sehari-hari dan masalah yang mungkin terkait, sebagian dari paparan dan penggunaan internet. Sehingga perlu bagi seorang praktisi untuk dilatih dengan baik dan kompeten dalam mendukung penggunaan konseling online. Lebih lanjut peneliti menyarankan bahwa praktisi yang terampil perlu ada di tempat yang 
sering menggunakan digital pada kalangan anak muda untuk menawarkan pilihan tambahan pertemuan tatap muka agar dapat mendukung dan memungkinkan kalangan anak muda menemukan jalan keluar dari masa-masa sulit. Selain itu, Asosiasi Australia untuk Penelitian dalam Pendidikan Konferensi (AARE) di Brisbane menantang para profesional sekolah, yang bekerja dengan remaja, untuk menggunakan teknologi ini untuk membantu siswa yang membutuhkan bantuan konseling. Mereka mengusulkan hal itu untuk memanfaatkan cara bekerja secara online. Selain itu pelatihan pengembangan keterampilan tambahan akan diperlukan sebagai prioritas, seperti kebutuhan untuk pelatihan dan bagaimana mengembangkan keterampilan untuk latihan dalam menggunakan konseling online.

\section{When Do People Seek Internet Counseling? Exploring the Temporal Patterns of Initial Submissions to Online Counselling Services (Tirel, Rozgonjuk, Purre, \& Elhai, 2019)}

Konseling melalui internet sebagian besar berbasis teks sehingga klien dan konselor melakukan komunikasi melalui e-mail, ruang obrolan maupun forum tetapi dengan panggilan video dan suara juga digunakan. Konseling melalui internet juga memiliki beberapa tantangan di mana tantangan yang paling penting adalah kurangnya petunjuk nonverbal seperti gestur tubuh dan ekspresi wajah kurangnya petunjuk komunikasi nonverbal dalam kasus konseling berbasis teks dapat membuat evaluasi menyeluruh masalah klien yang sulit. Namun, menyediakan layanan online dapat membantu mengurangi biaya sumber daya, dan dapat meningkatkan motivasi untuk spesialis. Misalnya, dua penyedia layanan konseling yang digunakan dalam penelitian ini menawarkan konseling melalui internet secara gratis, yang berarti bahwa keterbatasan finansial dalam pencarian bantuan dihilangkan. Selain itu, pengguna antarmuka memungkinkan kontak dengan penyedia layanan konseling online (atau konselor sendiri) secara langsung dan tanpa terlalu banyak kebutuhan kognitif. Dalam beberapa situasi, klien yang potensial dapat mengirim e-mail langsung ke konselor dan ditampilkan di situs $w e b$ penyedia layanan, seperti halnya dengan penyedia layanan yang digunakan dalam penelitian ini. Selain itu, biasanya, klien yang membutuhkan konseling tidak perlu menghabiskan sumber daya tambahan yang berkaitan dengan pendaftaran dan berpartisipasi dalam suatu sesi, seperti membuat janji temu melalui telepon atau bepergian ke pusat konseling atau klinik. Selain itu, klien bisa jadi berpendapat bahwa waktu tunggu hingga sesi awal bisa lebih pendek. Misalnya, konseling online memungkinkan untuk layanan yang akan tersedia hampir setiap saat, dan relatif lebih mudah untuk memulai sesi konseling online dengan mengirimkan konselor e-mail atau pesan. Sampel terdiri dari 3.291 orang yang menghubungi salah satu dari dua penyedia layanan konseling online paling populer (dilihat dari jumlah klien yaitu Lahendus.net, dan Peaasi.ee) di Estonia. Lahendus.net menyediakan data untuk 1.743 kontak pertama kali, dan dataset Peaasi.ee termasuk 1.548 orang. Rincian sampel dalam hal kelompok umur dan jenis kelamin dibentuk dalam satu tabel. Usia dikelompokkan ke dalam kelompok umur dalam kumpulan data Peaasi.ee sebagai berikut di bawah dan termasuk usia 12, 13-18, 19-26, 27, dan lebih tua. Hasil penelitian ini menunjukkan bahwa 
mereka yang membutuhkan konseling online biasanya pada musim dingin dan musim gugur serta pada sore hari.

Dalam hal ini, peneliti melakukan wawancara terhadap partisipan 10 kalangan muda usia 19-23 tahun dari berbagai macam latar belakang yaitu 5 pekerja, 3 mahasiswa dan 2 belum bekerja. Proses wawancara ini dilakukan semiterstruktur. Berikut ini adalah tabel partisipan:

Tabel 1.

Partisipan Kalangan Anak Muda

\begin{tabular}{cccc}
\hline No & Partisipan & Usia & Pekerjaan \\
\hline 1 & P 1 & 19 & Kasir \\
2 & P 2 & 20 & Guru SD \\
3 & P 3 & 22 & Karyawan Swasta \\
4 & P 4 & 23 & Tenaga Honorer \\
5 & P 5 & 23 & Karyawan Swasta \\
6 & M 1 & 19 & Semester 7 \\
7 & M 2 & 19 & Semester 7 \\
8 & M 3 & 20 & Semester 8 \\
9 & T 1 & 23 & Tidak Bekerja \\
10 & T 2 & 23 & Tidak Bekerja \\
\hline
\end{tabular}

Data di atas menunjukkan daftar partisipan kalangan anak muda. Wawancara diawali dengan memberikan pertanyaan terstruktur seputar konseling berbasis online sebagai upaya menangani masalah perundungan. Sejujurnya, saya sudah pernah merasakan perundungan sejak duduk di bangku Sekolah Menengah Pertama [M3, 2019]. Bagi saya perundungan merupakan sesuatu hal yang menyakitkan terlebih jika mengejek fisik [P3, 2019]. Saat ini saya mengalami masalah perundungan baik secara langsung di tempat kerja maupun media sosial karena gaya berpakaian pada saat bekerja [P4, 2019]. Sesekali saya merasa orang disekitar saya membicarakan dari belakang dan kemudian mulai mengejek saya tanpa alasan [T2]. Berdasarkan Emza (2015) perundungan merupakan suatu perbuatan yang dilakukan oleh manusia, baik secara individu maupun kolektif yang merupakan serangan berulang secara fisik, psikologis, sosial ataupun verbal untuk keuntungan atau kepuasan mereka sendiri. Ken Rigby dalam Cakrawati (2015) juga menambahkan bahwa perundungan adalah keinginan untuk menyakiti orang lain. Sehingga dari hasil wawancara terkait masalah perundungan, partisipan pernah mengalami perundungan baik di lingkungan kampus, maupun tempat kerja. Selain masalah perundungan, saya juga mengalami depresi namun sulit untuk diungkapkan karena rasa ketidakpercayaan kepada teman maupun keluarga [P1, 2019]. Saya pernah menceritakan permasalahan terkait depresi yang dialami dan juga perundungan di media sosial. Hanya saja orang yang saya ceritakan malah mengumbar kepada teman-teman yang lain [M2, 2019]. Menurut saya konseling online membantu dalam mengatasi masalah perundungan secara tidak langsung [P2, 2019]. Sebelumnya saya tidak tahu konseling online, tetapi pada saat melihat iklan di Youtube mengenai KALM sangat bermanfaat bagi pekerja seperti saya [P5, 2019]. Saya belum pernah menggunakan konseling online, karena yang saya tahu konseling hanya bisa dilakukan tatap muka [T1, 2019]. Saya tau salah satu konseling online yaitu riliv. Hanya saja saya belum paham untuk menggunakannya [P2, 2019]. Ada beberapa diantara pengguna 
konseling online yang merasakan kenyamanan bercerita mengenai masalah perundungan [konselor 1, 2019]. Menurut para kalangan anak muda, privasi mereka lebih terjaga ketika menggunakan konseling online [konselor 2, 2019]. Hanya saja memang konseling online kurang sosialisasi sehingga masih ada yang belum mengetahui keberadaanya [konselor 3, 2019].

Dari hasil temuan di atas menunjukkan bahwa di beberapa negara seperti India, Yunani, Australia, Scotlandia, Finlandia dan di Republik Estonia memberikan hasil positif terkait penggunaan konseling online. Dari hasil analisis pada 5 artikel tersebut menyatakan bahwa konseling online merupakan sesuatu hal yang efektif bagi kalangan anak muda dalam menceritakan masalah dan membantu menyelesaikan masalah. Rasa kepercayaan yang tinggi terhadap konseling online dikarenakan bersifat privasi dan mereka tidak perlu bertatap muka sehinggan intensitas emosional tidak begitu tinggi. Selain itu meminimalisir biaya sumber daya yang harus dikeluarkan. Temuan ini selaras dengan Zadrian, Yendi dan Ifdil (2013) bahwa konseling online merupkan pendekatan teknologi dalam pelayanan konseling yang memiliki beberapa keuntungan salah satunya terdapat rekaman yang permanen selama proses konseling berlangsung. Sehingga akan sangat bermanfaat bagi klien, konselor maupun supervisor konselor. Sejalan dengan hasil temuan pada wawancara, Ifdil dan Zadrian (2013) juga menambahkan bahwa konseling online sangat bergantung pada dukungan media. Karena dari hasil wawancara terhadap partisipan 2 diantara 10 kalangan anak muda menyatakan belum mengetahui konseling online. Ifdil (2011) juga menjelaskan bahwa dalam proses konseling online harus melalui beberapa proses seperti persiapan, proses konseling, dan pasca konseling. Tahapan yang dijelaskan sejalan dengan hasil penelitian dari Paterson, Laajala dan Lehtela (2017) dan Tirel, Rozgonjuk, Purre dan Elhai (2019). Terdapat pula faktor penghambat dalam pelaksanaan konseling online berbasis teks yaitu konselor dan supervisor konselor. Faktor penghambat dari konselor itu sendiri adalah kurangnya pengetahuan atau kemampuan khusus yang dimiliki konselor dalam berkomunikasi melalui obrolan media dan kurangnya keterampilan dalam menulis teks untuk menghindari kesalahpahaman dengan pengguna konseling online. Demikian juga pengguna konseling online yang memiliki kekurangan dalam pemahaman menggunakan teknologi juga menjadi salah satu faktor penghambat.

\section{KESIMPULAN}

Hasil analisis ini menunjukkan bahwa sejak tahun 2008, konseling online sudah digunakan sebagai salah satu alat memudahkan kalangan anak muda untuk melakukan konseling salah satunya anak muda. Mereka tidak harus meluapkan emosinya secara langsung dan hanya membutuhkan waktu yang singkat. Meskipun begitu, beberapa kelemahan konseling online juga ikut dibahas. Berjalannya waktu, kelemahan itu dapat diatasi dengan penemuan terbaru dari penelitian terkait konseling online. Hanya saja dibutuhkan sosialisasi terkait tata cara penggunaan konseling online terhadap kalangan anak muda terutama mereka yang sudah bekerja. Karena bukan hanya masalah perundungan yang sering kali ditemui tetapi juga depresi karena pekerjaan. Kemudian dibutuhkan juga pelatihan peningkatan keterampilan bagi konselor dalam melakukan pelayanan melalui konseling online. 


\section{DAFTAR PUSTAKA}

Amritesh Subhas Chandra Misra Jayanta Chatterjee. 2014. Emerging scenario of online Counsseling services in India: a case of e-government intervention. Transforming Government: People, Process and Policy, (8) 4, 569 - 596.

Ardi, Z., Yendi, F.M., Ifdil, I. 2013. Konseling online: sebuah pendekatan teknologi dalam pelayanan konseling. Journal Konseling dan Pendidikan, 1(1).

Barak, A., Klein, B., \& Proudfoot, J. G. 2009. Defining internet supported therapeutic Interventions. Annals of Behavioral Medicine, 38, 4-17. doi:10.1007/s12160-0099130-7.

Dowling, M., \& Rickwood, D. 2013. Online counseling and therapy for mental health problems: A systematic review of individual synchronous interventions using chat. Journal of Technology in Human Services, 31(1), 1-21. doi:10.1080/1 5228835.2012.728508.

Elinda Emza. 2015. Fenomena Bullying di Sekolah Dasar Kawasan Beresiko Kota Yogyakarta. Skripsi Fakultas Ilmu Pendidikan. Universitas Negeri Yogyakarta.

Fitria Cakrawati. 2015. Bullying, Siapa Takut? Cetakan I. Solo: Iga Ananda, Solo

Galderisi, S., Heinz, A., Kastrup, M., Beezhold, J., \& Sartorius, N. 2015. Toward a new definition of mental health. World Psychiatry: Official Journal of the World Psychiatric Association (WPA), 14(2), 231-233.

Gainsbury, S., \& Blaszczynski, A. 2011. A systematic review of internet-based therapy for the treatment of addictions. Clinical Psychology Review, 31, 490-498. doi:10.1016/j.cpr.2010.11.007.

Hanley, T., \& Reynolds, D. 2009. Counselling Psychology and the internet: A review of the quantitative research into online outcomes and alliances within text-based therapy. Counselling Psychology Review, 24(2), 4-13.

Hanley, T. 2006. Developing youth-friendly online counseling services in the United Kingdom: A small scale investigation into the views of practitioners. Counselling and Psychotherapy Research, 6, 182-185.

Haryadi, R., Rahmah, F.N., Khatimah, K., \& Irmahwati, S. 2019. Faktor penghambat dalam pelaksanaan konseling online berbasis teks(chat). Jurnal Mahasiswa BK An-Nur, $5(2)$.

Ifdil, I., \& Ardi, Z. 2013. Konseling online sebagai salah satu bentuk pelayanan e-konseling. Jurnal Konseling dan Pendidikan, 1(1).

Jeannie Wright. 2002. Online counselling: Learning from writing therapy. British Journal of Guidance \& Counselling, 30(3), 285-298. DOI: 10.1080/030698802100002326. 
Kessler, R. C., Angermeyer, M., Anthony, J. C., R, D. E. G., Demyttenaere, K., Gasquet, I. Ustun, T. B. 2007. Lifetime prevalence and age-of-onset distributions of mental disorders in the World Health Organization's World Mental Health Survey Initiative. World Psychiatry, 6(3), 168-176.

King, R., Bambling, M., Lloyd, C., Gomurra, R., Smith, S., Reid, W., \&Wegner, K. 2006. Online counselling: The motives and experiences of young people who chose the internet instead of face-to-face or telephone counseling. Counselling and Psychotherapy Research, 6, 169-174.

King, R., Bambling, M., Reid, W., \& Thomas, I. 2006. Telephone and online counselling for young people: A naturalistic comparison of session outcome, session impact and therapeutic alliance. Counselling and Psychotherapy Research, 6, 175-181.

Kurt D. Baker \& Mike Ray. 2011. Online counseling: The good, the bad, and the possibilities, Counselling Psychology Quarterly, 24(4), 341-346. doi:10.1080/09515070.2011.632875.

Lekka, F., Efstahiou, G. \& Azizi, A K. 2015. The effect of counseling-based training on online peer support. British Journal of Guidance \& Counselling, 43(1), 156-170.

Lydia Chardon, Karl S. Bagraith \& Robert John King. 2011. Counseling activity in Singlesession online counseling with adolescents: An adherence study. Psychotherapy Research, 21(5), 583-592. doi:10.1080/10503307.2011.592550.

Maheu, M. M., Pulier, M. L., McMenamin, J. P., \& Posen, L. 2012. Future of telepsychology, telehealth, and various technologies in psychological research and practice. Professional Psychology: Research and Practice, 43, 613-621. doi:10.1037/ a0029458.

Maili Tirel, Dmitri Rozgonjuk, Merle Purre \& Jon D. Elhai. 2019. When Do People Seek Internet Counseling? Exploring the Temporal Patterns of Initial Submissions to Online Counseling Services. Journal of Technology in Human Services. doi:10.1080/15228835.2018.156134.

Matthew Bambling, Robert King, Wendy Reid \& Karly Wegner. 2008. Online counselling: The experience of counsellors providing synchronous single-session counselling to young people. Counselling and Psychotherapy Research: Linking research with practice, 8(2), 110-116. doi: 10.1080/14733140802055011.

Mallen, M., Vogel, D., Rochlen, A., \& Day, S. 2005. Online counselling: Reviewing the literature from a counselling psychology framework. The Counselling Psychologist, 33, 819-871.

Maya, Nur. 2015. Fenomena Cyberbullying di Kalangan Pelajar. Jurnal Ilmu Sosial dan Ilmu Politik, 4(3), 443-450.

Perle, J. G., Langsam, L. C., \& Nierenberg, B. 2011. Controversy clarified: An updated review of clinical psychology and tele-health. Clinical Psychology Review, 31, 1247-1258. doi:10.1016/j.cpr.2011.08.003. 
Paterson, S.M., Laajala T. \& Lehtelä, P.-L. 2017. Counsellor students' conceptions of online counselling in Scotland and Finland. British Journal of Guidance \& Counselling. doi: 10.1080/03069885.2017.1383357.

Rahayu, Flourensia Sapty. 2012. Cyberbullying Sebagai Dampak Negatif Penggunaan Teknologi Informasi. Journal of Information System, 8(1), 22-31.

Rastati, Ranny. 2016. Bentuk perundungan siber di media sosial dan pencegahannya bagi korban dan pelaku. Jurnal Sosioteknologi, 15(2), 169-186.

Rodda, S. N., Lubman, D. I., Dowling, N. A., \& McCann, T. V. 2013. Reasons for using webbased counselling among family and friends impacted by problem gambling. Asian Journal of Gambling Issues and Public Health, 3 (12). doi:10.1186/2195-3007-3-12.

Safaria, Triantoro. 2015. Are Daily Spiritual Experiences, Self-Esteem and Family Harmony Predictors of Cyberbullying Among High School Student? International Journal of Research Studies in Psychology, 4(3), 23-34.

Saryono, \& Rithaudin, A. 2011. Meta analisis pengaruh pembelajaran pendekatan taktik (TGfU) terhadap pengembangan aspek kognitif siswa dalam pendidikan jasmani. Jurnal Pendidikan Jasmani Indonesia, 8(2), 144-151.

Silviandari, Ika Adita. 2018. Konflik peran dan perundungan (bullying) di tempat kerja: studi meta analisis. MEDIAPSI, 4(2).

Sucala, M., Schnur, J. B., Constantino, M. J., Miller, S. J., Brackman, E. H., \& Montgomery, G. H. 2012. The therapeutic relationship in e-therapy for mental health: A systematic review. Journal of Medical Internet Research, 14(4), 110. doi:10.2196/jmir.2084.

Tartakovsky, M. 2013. What prevents people from seeking mental health treatment? Retrieved from https://psychcentral.com/blog/archives/2013/01/14/whatprevents-peoplefrom-seeking-mental-health-treatment.

World Health Organization. 2004. Promoting mental health: Concepts, emerging evidence, practice: Summary report.

Wilson, S. R., Rodda, S., Lubman, D. I., Manning, V., \& Yap, M. B. H. 2017. How online counselling can support partners of individuals with problem alcohol or other drug use. Journal of Substance Abuse Treatment, 78, 56-62. doi:10.1016/j.jsat.2017.04.009. 